\title{
AL-AZHAR DALAM MEMODERNISASI PENDIDIKAN ISLAM
}

\author{
Hartono \\ hartono4alazhar@gmail.com \\ Dosen Magister Pendidikan Islam, Universitas Muhammadiyah Tangerang
}

\begin{abstract}
This study examines the efforts of Al Azhar in modernizing Islamic education in the efforts of superior school. The conclusion of the study is the existence of modernization of Islamic education in Al Azhar school which has been around since its exist, namely by emphasizing the quality of Islamic education at that time, besides no one has quality Islamic education which integrates science and religion to achieve the superior value.
\end{abstract}

Keyword : Modernization, Superior school and Integrates science.

\section{A. PENDAHULUAN}

Kajian ini menjelaskan tentang inti kondisi realitas sebenarnya lembaga pendidikan yang secara sampel berada pada sekolah Al-Azhar pusat yang berlokasi Jalan sisingamangaraja Kebayoran Baru, Jakarta Selatan.

Latar belakang muncul sekolah AlAzhar merupakan sebagai jawaban terhadap kondisi pendidikan umat Islam ketika itu yang mendambakan pendidikan yang bernuansa Islami dan mempunyai nilai keunggulan. Penyebab yang lain yaitu sebagai upaya untuk menfasilitasi orang tua murid agar memasukan anak-anaknya pada sekolah Islam.

Dengan motivasi untuk mengibarkan sekolah Islam yang berada pada sekitarnya sekolah non muslim, stakeholder berupaya untuk meningkatkan mutu pendidikan sehingga yang pada awal peminatnya dari kalangan masyarakat ekonomi lemah yang pada akhirnya tersortir secara alami sehingga mendominasi masyarakat elit muslim.

\section{B. KERANGKA TEORI}

Pembahasan modernisasi pendidikan Islam memiliki hubungan dengan istilah kunci lain berupa modernitas dan modernisme. Masing-masing istilah mewakili ekspresi makna tersendiri. Ada beberapa penulis yang telah memaknai tiaptiap istilah di atas. Penelitian ini memaknainya sebagai berikut: Modernitas merujuk pada berbagai perkembangan terbaru, baik yang bersifat material maupun abstrak sebagai hasil pikiran manusia untuk mengendalikan tantangan lingkungannya. Penggunaan hand phone (HP), agunan tunai mandiri (ATM) sampai kehadiran sekolah internasional adalah bentuk formal dari modernitas. Modernisme lebih merujuk pada objek yang sifatnya abstrak dan mewakili satu suasana intelektual. Substansi modernisme berada pada sikap menghargai waktu dan mandirisasi akal manusia untuk menghadapi kehidupannya dari berbagai ketergantungan terhadap alam, budaya dan dogma. Adapun modernisasi merujuk pada pengertian kerja atau proses merasionalkan, mensistematiskan dan mengendalikan 
realitas sosial dan alam agar sesuai dengan kebutuhan manusia. Sehingga komunitas atau masyarakat yang memfungsikan tiga makna istilah di atas disebut juga masyarakat modern.

Makna modernisasi merupakan fikiran, aliran, gerakan dan usaha untuk mengubah faham-faham, adat istiadat, institusi-institusi lama dan sebagainya untuk disesuaikan dengan suasana baru yang ditimbulkan oleh kemajuan ilmu pengetahuan dan tehnologi moderen.

Kemajuan ilmu pengetahuan dan tehnologi moderen memasuki dunia Islam, terutama sesudah pembukaan abad ke $19 \mathrm{M}$, yang dalam sejarah Islam dipandang sebagai permulaan periode Moderen. Kontak dengan dunia Barat selanjutnya membawa ide-ide baru ke dunia Islam seperti rasionalisme, nasionalisme, demokrasi dan sebagainya.

Modernisasi atau pembaharuan dapat diartikan dengan apa saja yang belum difahami, diterima atau dilaksanakan oleh penerima pembaruan, meskipun bukan hal baru bagi orang lain. Pembaruan biasanya dipergunakan sebagai proses perubahan untuk memperbaiki keadaan yang ada sebelumnya ke cara atau situasi dan kondisi yang lebih baik dari sebelumnya. Dengan kata lain, pembaruan sesungguhnya lebih merupakan upaya atau usaha perbaikan keadaan, baik dari segi cara, konsep dan serangkaian metode yang bisa diterapkan dalam rangka mengantarkan keadaan yang lebih baik.

\section{METODOLOGI}

Penelitian dalam rangka penulisan ini termasuk kategori penelitian kualitatif yang menekankan analisis terhadap dinamika hubungan antar fenomena yang diamati dengan menggunakan logika ilmiah.

Penggunaan metode kualitatif dilakukan melalui wawancara intensif (depth interview) yang mendalam dan pengamatan di sekolah objek. Wawancara digunakan untuk mendapatkan informasi tentang latar belakang dan obsesi penyelenggaraan sekolah Islam yang unggul dan moderen.

Selain itu juga menggunakan pengamatan terlibat yakni pengamatan yang dilakukan dengan ikut berperan serta dalam kehidupan orang-orang yang diteliti. Dengan menyebutkan pengamatan terlibat adalah strategi lapangan yang secara simultan memadukan analisis dokumen, wawancara dengan responden, partisipasi dan observasi langsung dan introspeksi. Kemudian dilakukan analisis data yang dilakukan dengan cara interaktif dan berlangsung secara terus menerus sampai tuntas sehingga datanya sudah jenuh. Aktifitas analisis data yaitu data reduction, data display dan conclusion drawing/verification.

\section{PEMBAHASAN}

Dengan motivasi untuk mengibarkan sekolah Islam moderen, stakeholder berupaya untuk meningkatkan mutu pendidikan yaitu pada awal peminatnya dari kalangan masyarakat ekonomi lemah yang pada akhirnya tersortir secara alami sehingga mendominasi masyarakat elit muslim dan dengan Integrasi Imtaq dengan Iptek.

\section{Masyarakat Elit Muslim}

Menurut Azra, pendahulu dari sekolah - sekolah elite dewasa ini adalah sekolah Islam Al-Azhar yang berlokasi di dalam kompleks Masjid Agung Al-Azhar di Kebayoran Baru, sebuah lingkungan di Jakarta Selatan.

Salah satu perkembangan yang paling mencolok dewasa ini dalam fenomena santrinisasi masyarakat Muslim Indonesia adalah munculnya sekolah - sekolah elite Muslim yang dikenal sebagai Sekolah Islam. Pada tahap awal perkembangannya, umumnya mereka dikenal sebagai Sekolah Islam yang disebut sebelumnya. Namun, sejak awal tahun 90-an, sebagian dari sekolah - sekolah itu mulai menyatakan dirinya secara formal atau sebaliknya diakui oleh banyak kaum Muslim sebagai sekolah 
unggul atau sekolah Islam unggulan. Istilah lain yang digunakan untuk menggambarkan sekolah - sekolah tersebut ialah SMA Model atau Sekolah Menengah Atas (Islam) Model.

Seiring dengan semakin meningkat popularitas Al-Azhar, berkembang pula sejumlah sekolah elite Islam lainnya, tidak hanya di wilayah Jakarta, melainkan juga di beberapa provinsi lain di Indonesia. Di antara sekolah - sekolah semacam itu adalah Sekolah Al-Azhar di Pondok Labu, Jakarta, SMA Insan Cendikia di Serpong dan SMA Madania di Parung, sebuah wilayah pinggiran di Selatan Jakarta dan lain-lain.

Labelisasi sebagai sekolah elit muslim, perlu ditekankan bahwa sekolah tersebut mempunyai program dan kepedulian terhadap masyarakat yang secara ekonomi dikatakan masyarakat bawah sebagai bentuk kepedulian.

Muncul dan berkembang Sekolah unggulan Islam yang baik tampaknya memiliki dampak - dampak yang berjangkauan luas terhadap masa depan masyarakat Muslim Indonesia. Sekolah sekolah menawarkan pendidikan berkualitas tersebut tidak hanya memberi kontribusi pada perbaikan pendidikan Islam di Indonesia, melainkan juga pada proses santrinisasi masyarakat Muslim.

Dengan demikian, sebuah pola baru reislamisasi atau santrinisasi muncul dibelakang kelas menengah Muslim, tidak hanya di kalangan anak - anak, tetapi juga di kalangan orangtua. Pola baru santrinisasi ini agak unik. Secara tradisional, santrinisasi di anggap dilakukan terutama oleh para da'i melalui kegiatan - kegiatan dakwah. Dakwah biasanya dilakukan melalui pengajian di masjid - masjid, atau di tempat - tempat lainnya yang kaum Muslim melaksanakan kagiatan - kegiatan keagamaan. Ada semacam ketidakpuasaan, bahkan kritik, terhadap tipe dakwah lisan ini. Oleh sebab itu, pada tahun - tahun belakangan muncul jenis baru kegiatan dakwah, yang lebih menekankan pada tindakan daripada sekedar kata - kata. Tipe baru dakwah ini dikenal sebagai da'wah bil hal, dakwah melalui tindakan.

Fenomena santrinisasi ini tampaknya berbeda dari kedua jenis dakwah yang telah disebutkan. Proses santrinisasi melalui sekolah - sekolah elite Muslim dapat dikatakan merupakan semacam dakwah diam - diam atau lebih merupakan dakwah organic. Tidak ada dakwah formal dari ruang pengajian.

Tidak hanya para orangtua Muslim yang mengirimkan anak mereka ke sekolah elite Islam itu percaya bahwa anak mereka akan memperoleh pandangan dan pemahaman yang lebih komprehensif tentang Islam kini, boleh merasa yakin bahwa anak mereka akan mendapatkan pengetahuan dan pemahaman yang lebih luas tentang ajaran Islam. Lebih dari itu, anak - anak mereka diajarkan tentang bagaimana memperhatikan ajaran - ajaran Islam dalam kehidupan sehari - hari. Misalnya, mereka tidak hanya diajarkan untuk melaksanakan salat wajib lima waktu, tetapi juga diajarkan untuk memimpin salat itu sendiri atau menjadi khotib jum'at.

Sebagaimana yang dikatakan Azra bahwa Al-Azhar merupakan pendahulu sekolah elit muslim, maka perlu diketahui latar belakang pada sekolah tersebut.

Pemberian nama Al-Azhar mengulang pemberian nama serupa kepada "Masjid Jami'al-Qahirah" bagi Masjid tersebut karena letaknya berada di al-Qahirah (Kairo), Mesir. Dan berganti menjadi nama "Al-Azhar" karena dinisbatkan kepada nama Fatimah al-Zahra, putri Rasulullah Shallallahu alaihi wa-sallam. Dan hampir seribu tahun berikutnya, Syeikh Jami' AlAzhar, Kairo, memberi nama Masjid Agung, dengan nama Masjid Agung Al-Azhar.

Mesir maupun Al-Azhar bagi masyarakat Jakarta khususnya, dan Indonesia pada umumnya tidak asing. Kedua negara tersebut, sama-sama memeluk Islam. Dan masyarakat Indonesia sudah lama mengenal Mesir sebagai salah satu pusat 
pendidikan Islam. Banyak pelajar Indonesia belajar di Mesir, khususnya di Al-Azhar.

Masjid dijadikan awal kegiatan umat. Jamaah yang duduk melingkar pengajaran (halaqah) yang diadakan di masjid - masjid semenjak masjid didirikan. Keadaan seperti itu berjalan terus sepanjang tahun di seluruh negeri Islam.

Di masjid Agung Al-Azhar keadaannya juga tidak jauh berbeda dengan negeri negeri Islam lainnya. Setelah shalat subuh Imam Besar, Buya Hamka, menggelar pengajian, mengupas isi kandungan AlQur'an di depan para jamaah yang duduk bersila mengelilinginya. Sedang sore harinya, anak-anak kecil belajar membaca dan menulis Al-Qur'an. Mereka duduk bersila di depan Kitab Suci Al-Qur'an yang diletakkan di atas rehal masing - masing.

Lambat laun, anak-anak yang mengaji terus bertambah. Materi yang diajarkan tidak lagi hanya membaca dan menulis Al-Qur'an, tapi juga Al-Hadits, karena keduanya (AlQur'an dan Al-Hadits) merupakan sumber utama Agama Islam. Juga belajar tauhid, ibadah, akhlak, serta tarikh. Kemudian duduknya tidak lagi bersila di depan rehal, melainkan dibangku - bangku panjang dari kayu.

Dalam suasana seperti itu Pengurus dan Jamaah Masjid Agung Al-Azhar berusaha menghidupkan dan memakmurkan rumah Allah. Murid-murid yang mengaji sore hari sebisa mungkin tetap dijalankan, meski tampak sederhana. Padahal Masjid tempat mereka belajar cukup megah dan besar.

Salah seorang jamaah Masjid Agung Al-Azhar, Abdullah Hakim, mengusulkan (Maret 1963) agar pengajian sore hari ditingkatkan mutu dan penyelenggaraannya, sepadan dengan kemegahan Masjid Agung Al-Azhar. Yaitu dengan membentuk suatu lembaga pendidikan yang di dalamnya terdiri TK, SD, SMP, SMA bahkan sampai ke Perguruan Tinggi.

Berbagai tanggapan bermunculan, mendukung usulan tersebut, sehingga dengan mudah pertemuan mengambil beberapa keputusan.

Setelah pertemuan, pembicaraan dilanjutkan lebih khusus lagi dengan melakukan penjajagan ke berbagai kalangan. Dan pada tahun 1963, Sekolah Islam Sore, sejenis Madrasah Diniyah yang kelak diberi nama Pendidikan Islam Al-Azhar (PIA) dibuka. Setahun berikutnya, awal Agustus 1964, TK Islam Al-Azhar dan SD Islam AlAzhar. kemudian SMP Islam Al-Azhar (th. 1971), serta SMA Islam Al-Azhar (th. 1976) dan Universitas Al-Azhar Indonesia (th. 2000).

Sekolah - sekolah dalam lingkungan Masjid Agung Al-Azhar, diawali dengan dibukanya madrasah sore -Khusus Agama, semacam Madrasah Diniyah yang kelak bernama Pendidikan Islam Al-Azhar / PIA-. Kemudian tahun berikutnya (1 Agustus 1964) Taman Kanak - Kanak Masjid Agung ( TK Islam Al-Azhar) dan Sekolah Dasar Masjid Agung ( SD Islam Al-Azhar).

Oleh karena itu, pada 10 Juni 1975, Badan Pengurus YPI Al-Azhar memisahkan secara struktural masalah pendidikan dari pengurusan Masjid, sehingga menjadi Bagian Pendidikan YPI Al-Azhar. Sedangkan kepengurusannya terdiri dari Mochtar Zakaria (Ketua, kelak menjadi Walikota Jakarta Selatan), Sofyan Saad (Sekretaris), H Moegni (Bendahara), serta H. M. Sanusi, Jacub Rasjid, R. Soemedji Moefti dan Hanafi (masing - masing sebagai pengurus pleno).

Pengelolaan pendidikan yang demikian, bertahap hasilnya mulai terlihat setelah murid - murid SMP Islam Al-Azhar menamatkan pendidikannya di tahun 1976, YPI Al-Azhar kemudian membuka SMA Islam Al-Azhar, kemudian SD Islam AlAzhar II (1978), dan SD Islam Al-Azhar Cabang Pasar Minggu, dan seterusnya.

Dengan demikian dasar pengembangan sekolah di Al-Azhar Indonesia berasal dari pengembangan kegiatan dari masjid. Hal ini mempunyai kesamaan dengan Al-Azhar Kairo, Mesir 
yaitu mempunyai lembaga pendidikan Islam yang berawal dari pengembangan kegiatan masjid. Kondisi ini relevan apa yang dikatakan Ya'qub bin Kalas (menteri dijaman khalifah Al-Aziz Billah ) agar fungsi masjid dikembangkan ke arah lembaga pendidikan. Maka tak lama kemudian muncul pemikiran studi di AlJami' Al-Azhar pada akhir masa Al-Mu'iz Lidinillah Al-Fatimi pada bulan Shafar 365 H ( Oktober 975 M).

Pada awal sekolah Al-Azhar bukan berasal dari masyarakat elit muslim tetapi murid-muridnya berasal dari masyarakat ekonomi kelas bawah yang ingin memperoleh pendidikan. Masyarakat elit muslim di lingkungan sekolah Al-Azhar muncul karena tertarik terhadap proses dan hasil pendidikan yang ketika itu pada tahun 1970 an meraih prestasi sebagai sekolah Islam terbaik di Jakarta yang menimbulkan minat orang tua untuk mendaftarkan anakanaknya pada lembaga tersebut.

Minat orang tua sangat tinggi dan banyak yang ingin mendaftarkan anakanaknya dapat diketahui melalui bersedia memberikan pembiayaan pendidikan yang mahal asalkan anak-anaknya dapat diterima. Kemudian dapat diketahui pula dengan keterbatasan kelas daya tampung, mereka berlomba-lomba memberikan biaya tambahan untuk mendirikan gedung baru asalkan anak-anaknya dapat diterima.

\section{Integrasi Imtaq dengan Iptek.}

Dunia pendidikan Islam sebagian masih mengikuti platform keilmuwan Islam klasik yang didominasi ilmu-ilmu agama. Memasuki periode moderen ,tradisi itu mengalami kesenjangan dengan perkembangan ilmu pengetahuan dan teknologi yang telah kuat mempengaruhi peradaban manusia dewasa ini. Kesenjangan telah menghadapkan dunia pendidikan Islam dengan tiga situasi yang buruk: pertama, dikotomi yang berkepanjangan antara ilmu agama dengan ilmu umum,1) kedua, keterasingan pengajaran ilmu-ilmu keagamaan dari realitas kemoderenan, dan ketiga, menjauhnya kemajuan ilmu pengetahuan dari nilai-nilai agama.2). Merespon ketiga situasi tersebut para sarjana muslim mengusulkan perlunya usaha pemaduan ilmu-ilmu agama dengan ilmuilmu modern,antara lain dengan memunculkan gagasan dan proyek Integrasi ilmu pengetahuan.

Sebagian sarjana muslim melihat secara objektif bahwa tradisi keilmuwan Islam yang berkembang hingga masa moderen lebih didominasi oleh tradisi ilmu agama. Menurut 'Abd. Hamid Abu Sulaiman, tradisi pemikiran Islam klasik memiliki kelemahan, karena terbatas pada kajian teks dalam bidang bahasa, hadits dan fiqh. Sejauh ini perhatian hanya diarahkan kepada al-'ulum al-syar'i, maka jelas tradisi keilmuwan Islam klasik dipandang tidak cukup untuk menangani problem ilmu pengetahuan moderen . Karena menurut Ismail Faruqi, proyek Islamisasi ilmu pengetahuan harus dapat membangun kerangka filosofis baru yang berpusat pada konsep yang paling fundamental yakni Tauhid (Keesaan Tuhan). Dengan basis tauhid dapat mengatasi kerangka pemikiran Islam klasik.

Usulan Integrasi sering dilihat atau ditampilkan dalam kerangka yang ideologis sehingga diasosiasikan dalam bentuk usahausaha yang kurang apresiatif terhadap bangunan-bangunan ilmu pengetahuan modern. Integrasi ilmu pengetahuan sebagaimana yang sudah berkembang dewasa ini. Kesan ini terlalu berlebihan dan menepis substansi gagasan integrasi itu sendiri sehingga dalam kasus Indonesia upaya integrasi belum mendapat perhatian yang serius.

Integrasi ilmu pengetahuan pada dasarnya merupakan suatu respon terhadap krisis masyarakat modern yang disebabkan karena pendidikan Barat yang bertumpu pada suatu pandangan dunia yang lebih bersifat materialistis,3) yang menganggap bahwa pendidikan bukan untuk membuat

Tadarus Tarbawy. Vol. 2 No. 1 Jan - Jun 2020. ISSN. 2657-1285 e-ISSN. 2656-8756 
manusia bijak yakni mengenali dan mengakui posisi masing-masing dalam tertib realitas tapi memandang realitas sebagai sesuatu yang bermakna secara material bagi manusia, dan karena itu hubungan manusia dengan tertib realitas bersifat ekspoitatif bukan harmonis.

Integrasi Ilmu pengetahuan juga merupakan upaya pembebasan pengetahuan dari asumsi-asumsi Barat terhadap realitas dan kemudian menggantikannya dengan pandangan dunia Islam.

Selain itu integrasi ilmu pengetahuan muncul sebagai reaksi terhadap adanya konsep dikotomi antara agama dan ilmu pengetahuan yang dimasukkan masyarakat Barat dan budaya masyarakat modern.

Pada perspektif sejarah, Sains dan Tehnologi modern telah menunjukkan keberhasilannya dewasa ini mulai berkembang di Eropa dalam rangka gerakkan Renaisans pada tiga atau empat abad silam. Gerakan ini berhasil menyingkirkan peran agama dan mendobrak dominasi gereja Roma dalam kehidupan sosial dan intelektual masyarakat Eropa sebagai akibat dari sikap gereja yang memusuhi ilmu pengetahuan. Dengan kata lain Ilmu pengetahuan di Eropa dan Barat mengalami perkembangan setelah memisahkan diri dari pengaruh agama. Kemudian berkembang pendapat-pendapat yang merendahkan agama dan meninggikan sains.

Jika di Eropa sains dan tehnologi dapat berkembang sesudah mengalahkan dominasi gereja, sedangkan dalam perjalanan sejarah Islam lain halnya, ilmu yang menjadi pengetahuan dan hikmah, dalam berbagai bidangnya mengalami kemajuan yang pesat di dunia Islam pada zaman klasik (670-1300 M), yaitu sejak zaman nabi Muhammad Saw sampai dengan akhir masa daulah Abbasiyah di Badgdad. Dalam hubungan ini, Harun Nasution mengatakan bahwa cendekiawan Islam bukan hanya ilmu pengetahuan dan filsafat yang mereka pelajari dari buku-buku Yunani, tetapi menambahkan ke dalam hasil-hasil penyelidikan yang mereka lakukan sendiri dalam lapangan ilmu pengetahuan dan hasil pemikiran mereka dalam ilmu filsafat. Maka timbullah ahli-ahli ilmu pengetahuan dan filosof-filosof muslim.

Konsep ajaran Islam tentang pengembangan ilmu pengetahuan didasarkan kepada beberapa prinsip, yaitu : pertama, Ilmu pengetahuan dalam kerangka tauhid dalam arti luas, yaitu yang dikembangkan bukan saja keterkaitan dengan keimanan kepada Allah, juga menyangkut aktifitas mental berupa kesadaran manusia dalam hubungannya dengan lingkungan dan sesamanya yang mempunyai implikasi sosiologis dan antropologis. Manusia dalam pandangan Islam adalah ciptaan Allah. Secara fisik manusia terikat dengan sunnatullah, dan secara psikis ia terikat oleh nilai-nilai Ilahiyah atau kecenderungan pada agama dan kebenaran. Dengan demikian manusia merupakan ayat Allah . Orang yang mengenal dirinya, maka akan mengenal Tuhannya. Kedua, Dikembangkan dalam rangka bertakwa dan beribadah kepada Allah, karena motivasi utama untuk mengembangkan ilmu yang didorong keikhlasan dan tanggung jawab kepada Allah. Ketiga, Pengembangan ilmu dalam bentuk lahiriah, jangan sampai menghilangkan makna spiritualnya yang abadi, yakni sebagai alat untuk menyaksikan kebesaran Tuhannya. Roger Geraudi mencontohkan Ilmu Matematika disamping memiliki makna intelegible (dapat difikirkan) juga bermakna sensible (dapat dirasakan).4)

Substantif integrasi ilmu pengetahuan didasarkan pada panggilan ketika dunia ilmu pengetahuan dan tehnologi moderen memerlukan landasan moral dan spiritual yang konsisten. Dalam kesadaran masyarakat moderen sudah mulai dirasakan adanya paradoks ilmu pengetahuan yang cenderung menghasilkan malapetaka ketimbang berkah karena rapuhnya fondasi materialisme dan positivisme. Kegelisahan 
moral dan spiritual yang diderita masyarakat modern memunculkan fenomena bunuh diri massal atas nama penyelamatan surgawi. Sayyed Hossein Nasr mengingatkan bahwa penerapan sains modern menyebabkan bencana lingkungan yang tidak pernah terjadi sebelumnya dan bahkan menyebabkan kehancuran tata alamiah secara total. Kenyataan dunia ilmu pengetahuan yang tidak dapat mengatasi kegelisahan harus dikembalikan pada aspekaspek fundamental ilmu pengetahuan itu sendiri, sehingga penyelesaiannya memerlukan penanganan yang serius.

Manusia dituntut untuk memaknai hukum-hukum Allah yang kemudian diambil manfaatnya untuk membangun dunia. Namun demikian bahwa ilmu yang dijadikan pegangan tidak lepas begitu saja dari agama karena agama merupakan puncak dari pencapaian tersebut. Agama tidak mengadakan perubahan dan menjadi alat pembaharuan. Dari sini nampaknya jelas bahwa tidak ada dikotomi antara agama dan ilmu.5).

Al-Arabi 6) berpendapat bahwa ilmu tidak dapat dirumuskan dalam pengertian esensialnya serta tidak mungkin ditentukan batasan-batasannya karena ia meliputi segala ikatan . Tidak ada sesuatupun yang gemilang cahayanya selain dari pada ilmu yang tempat bersemayamnya di hati.

Pemisahan ilmu pengetahuan dari agama telah menyebabkan kerusakan yang tidak bisa diperbaiki. Keimanan dikenalkan lewat sains, keimanan bisa tetap aman dan terhindar dari tahayul melalui sains, keimanan tanpa sains akan mengakibatkan fanatisme dalam kemandekan.

Fenomena berkembang ilmu pengetahuan secara sendiri (otonom) dan terbebas dari ikatan agama dan sosial menandai abad ke 20 terutama setelah perang dunia ke dua. Akibatnya seringkali perencanaan yang dihasilkan ilmu pengetahuan bertabrakan dengan nilai-nilai religius seperti yang terjadi di Barat.
Menurut Azra,7) dikotomi terjadi seiring dengan terjadi perbedaan pemikiran yang menimbulkan adanya golongangolongan dalam Islam. Golongan Sunni ortodok yang secara terang-terangan menolak ilmu-ilmu yang bersumber dari daya nalar rasio manusia dan ilmu yang berdasarkan data empiris. Sementara golongan Mu'tazilah mempelajari ilmu-ilmu tersebut tidak lepas pemikiran yang berlandaskan bahwa ilmu-ilmu tersebut tidak selaras dengan kebenaran wahyu.

Dalam hubungan agama dan ilmu pengetahuan secara garis besar terdapat dua pandangan yang berkembang di Indonesia, tetapi kedua-duanya belum diwujudkan dalam usaha yang serius dan terus menerus . Sebagian berpandangan bahwa ilmu pengetahuan sebagai produk dari kegiatan ilmiah bersifat netral (bebas nilai). Meskipun lahir dan berkembang dalam masyarakat Barat yang sekuler, ilmu pengetahuan sebagaimana adanya dapat digunakan untuk kepentingan umat manusia . kaum muslimin dengan jiwa keislamannya dapat menggunakan ilmu pengetahuan itu dan dijamin tidak akan hanyut dalam arus sekulerisasi . Dalam konteks ini gagasan integrasi dipandang sebagai sikap apriori , semata-mata karena ilmu pengetahuan modern dikembangkan oleh ilmuwanilmuwan Barat.

Dalam menjawab tuntutan moral dan spiritual, pandangan yang menganggap ilmu pengetahuan sebagai bebas nilai ini mengusulkan perlunya pengembangan etika agama dalam kehidupan praktis secara fungsional. Sejauh ini agama lebih dipraktekkan dalam rangkaian-rangkaian ritual yang formal. Sebagai agama suci, Islam sesungguhnya memiliki dasar-dasar etis dalam semua aspek kehidupan yang menjadi landasan prilaku yang bermoral. Dalam diri manusia yang memiliki konsistensi inilah ilmu pengetahuan akan memberikan arti yang sesungguhnya bagi kemaslahatan umat manusia. 
Kalangan lain berpandangan bahwa ilmu pengetahuan modern mengandung materialisme dan positivisme sesuai dengan tradisi Barat. Ketika diusulkan perlu integrasi maka yang dimaksudkannya adalah bagaimana menggantikan nilai-nilai materialisme dan positivisme dengan nilainilai keagamaan yang lebih transendental. Paradigma positivistik dalam batas-batas tertentu memang sangat diperlukan dalam proses ilmiah, tetapi ia tidak dapat menjangkau dimensi-dimensi metafisik dan non material. Karena itu sepanjang ilmu pengetahuan dikuasai oleh nilai-nilai barat yang sekuler, kehampaan moral dan spiritual akan terus menghantui umat manusia dan pada gilirannya menghancurkan tatanan dunia secara keseluruhan.

Dikotomi pada kelanjutannya berdampak negatif terhadap kemajuan Islam.Menurut Ikhrom, setidaknya ada empat masalah akibat dikotomi ilmu-ilmu agama dengan ilmu umum.Pertama, munculnya ambivalensi dalam sistem pendidikan Islam. Kedua, Munculnya kesenjangan antara sistem pendidikan islam dan ajaran Islam. Sistem Pendidikan yang ambivalen mencerminkan pandangan dikotomis yang memisahkan ilmu agama Islam dengan ilmu umum. Ketiga, terjadi disintegrasi sistem pendidikan Islam, yang masing-masing sistem tetap bersikukuh mempertahankan kediriannya. Keempat, munculnya inferioritas pengelola lembaga pendidikan Islam. 8).

Pada tatanan yang paling sederhana, integrasi ilmu pengetahuan sering dilakukan dengan mencarikan doktrin-doktrin agama yang relevan. Pola ini diaplikasikan oleh kurikulum Al-Azhar , yaitu dengan mengambil dari sumber Al-Qur'an dan hadits yang relevan dengan materi kompetensi dasar, kemudian pendidik menyampaikannya dalam proses belajar mengajar.

Alasan pendekatan dipergunakan kurikulum Al-Azhar karena pada awalnya pada tahun 1990 telah disusun kurikulum yang didalamnya sudah diprogramkan secara tertulis dan terkandung integrasi Iptek dengan Imtaq yang dikenal dengan GBPP ( Garis-garis Besar Program Pengajaran ) AlAzhar yang diintegrasikan dengan Imtaq.Kemudian direncanakan untuk disosialisasikan kepada para pendidik dengan mengadakan workshop.

Program tersebut mengalami kendala , diantara permasalahannya adalah adanya perubahan kurikulum yang dibuat oleh Diknas sehingga kalaupun ingin dilanjutkan tentunya mengalami penyesuaianpenyesuaian atau perubahan.

Dengan kondisi ini, tetap melakukan integrasi ilmu pengetahuan, karena sudah menjadi kompetensi dan ciri khas pada lembaga pendidikan Islam tersebut. Pendidik melakukan improvisasi menurut kemampuan yang dimiliki masing-masing sehingga secara pengamatan terlihat dalam integrasi bervariatif. Artinya ada yang melakukannya sesuai dengan kompetensi dasar masingmasing, ada yang kurang menguasai karena keterbatasan kemampuan untuk melakukannya.

Upaya yang dilakukan secara tertulis oleh masing-masing pendidik dibuat integrasinya melalui program silabus tahunan, semester atau melalui RPP ( Rencana Program Pengajaran).

Menurut pandangan Al-Qur'an dan Sunah, sesungguhnya tidak ada istilah ilmu agama dan ilmu umum. Yang ada ilmu itu sendiri yang bersumber dari Allah SWT. Namun dilihat dari sifat dan jenisnya sulit dihindari adanya paradigma ilmu agama dan ilmu umum, atau paling tidak paradigma tersebut hanya untuk kepentingan teknis dalam membedakan antara satu ilmu dengan Ilmu lainnya. Dalam Islam terdapat beberapa pandangan : Pertama, Islam adalah suatu agama yang lengkap. Di dalamnya antara lain terdapat sistem ketatanegaraan atau politik.Tokohnya yaitu Hasan al-Banna, Sayyid Qutub, Muhammad Rasyid Ridha dan Abu al-A'la al-Maududi.9) 
Kedua, Islam adalah agama dalam pengertian Barat,yang tidak ada hubungannya dengan urusan kenegaraan.Tokohnya yaitu Ali Abd.Raziq dan Thaha Hussein.Ketiga, Islam tidak terdapat sistem ketatanegaraan, tetapi terdapat seperangkat tata nilai etika bagi kehidupan bernegara.Tokohnya yaitu Muhammad Husein Haikal.

Selanjutnya A. Malik Fadjar menambahkan satu aliran lain yaitu bahwa Islam adalah petunjuk hidup yang menghidupkan. Islam tidak memberikan petunjuk terhadap semua aspek kehidupan manusia yang bersifat baku dan operasional.

Bangunan ilmu pengetahuan moderen sepenuhnya diterima, hampir tanpa gugatan yang kritis, tetapi ditambahkan dan diperkuat dengan ketentuan-ketentuan teks al-Qur'an dan sunah yang mendukung.

Al-Qur'an dan Sunah dengan ayat-ayat dan matan menawarkan suatu penyelesaian atas terjadinya hal-hal yang sepertinya bertentangan namun sesungguhnya tidak demikian. Berkaitan dengan ini, terdapat beberapa contoh bahwa antara ilmu agama dan ilmu umum tidak bertentangan. Pertama, Agama memerintahkan manusia berfikir dengan menggunakan istilah Tatafakkarun,tatadabbarun, tatazakkarun, ta'aqqul, tafaquh, iqra dan seterusnya. Kedua, di dalam wahyu terdapat perintah Allah untuk melaksanakan ibadah, mengolah alam dalam rangka pelaksanaan fungsi sebagai khalifah di muka bumi, memecahkan masalah dalam kehidupan dan sebagainya. Untuk dapat melaksanakan perintah agama membutuhkan agama. Dengan kata lain perintah mengembangkan ilmu pengetahuan dalam Islam terintegrasi dengan perintah melaksanakan ibadah dan lainnya. Ketiga, agama berbicara tentang alam gaib, dan kepercayaan terhadap alam ghaib termasuk yang ditekankan dan menjadi ciri orang yang bertakwa. Adanya yang ghaib tidak bertentangan dengan sifat ilmu pengetahuan yang bertumpu pada halhal yang empiris, rasionalistik dan realistik.
Berbagai temuan telah sampai bahwa antara yang ghaib dan yang tampak terdapat hubungan yang fungsional, intensif dan saling mengisi.

Tahap yang signifikan dalam integrasi ilmu pengetahuan adalah usaha membangun basis-basis keislaman yang tangguh untuk semua disiplin ilmu.Usaha ini biasa disebut dengan Islamisasi Disiplin Ilmu (Islamization of Disciplines). Dari pada mempersoalkan aspek-aspek filosofis ilmu pengetahuan secara mendasar, Islamisasi disiplin ilmu lebih langsung menangani secara kritis ilmu-ilmu pengetahuan yang sudah berkembang. Keseriusan usaha ini terletak pada proses Identifikasi dan klasifikasi teori-teori yang relevan dan tidak relevan dengan Islam. Dengan demikian penggunaan dalil keagamaan tidak selalu untuk mengabsahkan teori yang ada, tetapi juga untuk menolak dan sekaligus menawarkan alternatif terhadap teori yang berlawanan dengan ajaran Islam. Proses ini secara otomatis ikut memperkaya teori-teori ilmu pengetahuan itu sendiri dengan adanya berbagai versi.

Usaha integrasi ilmu pengetahuan secara fundamental dilakukan dengan asumsi bahwa kerangka filosofis ilmu pengetahuan moderen masih sempit paling tidak untuk menampung prinsip kosmologi Islam yang tidak terbatas pada dunia empirik. Dengan demikian apa yang harus dilakukan adalah bagaimana membangun kerangka filosofis ilmu pengetahuan secara Islami. Masalahnya adalah dari mana dan dengan apa usaha membangun dengan kerangka filosofis itu dimulai. Dalam kenyataannya Islam sendiri memang memiliki tradisi keilmuwan yang panjang tetapi apakah tradisi itu cukup untuk mengganti tradisi keilmuwan moderen.

Dalam integrasi ilmu yag dilakukan oleh Al-Azhar, pengklasifikasian dilakukan berdasarkan Kompetensi Dasar masingmasing mata pelajaran untuk disesuaikan, kemudian dicari ayat-ayat atau hadits yang sesuai. Upaya ini dilakukan mengandung arti

Tadarus Tarbawy. Vol. 2 No. 1 Jan - Jun 2020. ISSN. 2657-1285 e-ISSN. 2656-8756 
sama dalam pendekatan imtaqnya yang kadangkala berkaitan dengan akidah, ibadah, akhlak, sejarah dan lain-lain artinya tidak ada penekanan khusus (Stressing ) yang bersifat fundamental.

Usaha membangun kerangka filosofis baru dalam rangka integrasi ilmu pengetahuan merupakan bahan pembahasan sejumlah sarjana muslim kontemporer . Alfaruqi sendiri jelas dalam monograf Islamization of Knowledge mengusulkan satu kerangka kerja Islamisasi ilmu pengetahuan mulai dari penguasaan disiplin ilmu sampai penyebaran ilmu pengetahuan yang sudah terislamkan. Untuk mematangkan gagasan ini,beberapa buku telah ditulis dan konferensi Islam dilaksanakan. Melengkapi tawaran al-Faruqi , Muhammad Arif mengusulkan penggunaan dua pendekatan stratification and Idealization yang masing masing dari Einstein dan Academic American Encyklopedia. Pendekatan pertama, Stratification, pada dasarnya adalah teoritisasi yang dimulai dengan peristiwa yang konkret menuju yang abstrak, sedang pendekatan kedua, idealization, berproses sebaliknya, mulai dari yang umum dan abstrak menuju yang konkret.10).

Ada beberapa model integrasi pengetahuan yang biasa dikembangkan dalam menatap era globalisasi, antara lain : model purifikasi, model modernisasi Islam dan model neo modernisme.11).

Purifikasi bermakna pembersihan atau penyucian. Dalam arti integrasi pengetahuan berusaha menyelenggarakan pengkudusan ilmu pengetahuan agar sesuai dengan nilai dan norma Islam. Model ini berasumsi bahwa dilihat dari dimensi normativeteologis, doktrin islam pada dasarnya mengajarkan kepada umatnya untuk memasuki islam secara kaffah/menyeluruh sebagai lawan dari berislam secara parsial. Islam kaffah (QS. Al- Baqarah : 208 ) diyakini mampu mewadahi berbagai dimensi kehidupan muslim.
Dengan melihat berbagai pendekatan yang dipakai A-Faruqi dan Al-Attas dalam gagasan Islamisasi ilmu pengetahuan, seperti 1). Penguasaan Khazanah Ilmu Pengetahuan Muslim. 2) Penguasaan khazanah ilmu pengetahuan masa kini. 3) Identifikasi kekurangan ilmu pengetahuan itu dalam hubungannya dengan ideal islam dan 4) rekonstruksi ilmu-Ilmu itu sehingga menjadi panduan yang selaras dengan warisan dan idealitas islam, maka gagasan islamisasi keduanya dapat dikategorikan dalam model purifikasi.

Terlepas dari langkah-langkah apa yang harus dilibatkan dalam kerangka filosofis Islam yang paling penting menurut Louay Safi adalah bagaimana menjadikan wahyu sebagai sumber ilmu pengetahuan. Hal yang terakhir ini secara signifikan menjadi ciri pokok dari usaha integrasi ilmu pengetahuan, untuk membedakannya dengan ilmu pengetahuan moderen yang bersumber dari kebenaran empiris. Namun demikian dalam prakteknya usaha ini tidak sederhana karena kenyataan bahwa ilmu pengetahuan modern tidak memberi tempat sama sekali pada wahyu. Tradisi keilmuwan Barat sekuler menganggap wahyu sepenuhnya sebagai bidang metafisik dan karena itu dianggap sebagai pengetahuan yang berada di luar jangkauan kebenaran rasional. Selain itu sebagaimana dinyatakan Immanuel Kant, proses saintifik hanya dalam batas-batas wilayah empirik mengingat akal manusia tidak dapat memikirkan realitas transendental. Bertolak belakang dengan kecenderungan modern, Safi nampaknya ingin menawarkan kerangka metodologis yang terpadu bagi ilmu-ilmu keagamaan dan ilmu-ilmu sosial yang menjamin posisi wahyu sebagai sentral dalam Islamisasi Ilmu Pengetahuan.12).

Modernisasi berarti proses perubahan menurut fitrah atau sunatullah, yang berangkat dari kepedulian terhadap keterbelakangan umat Islam di dunia kini, yang disebabkan kepicikan berfikir , kebodohan dan keterpurukan dalam 
memahami ajaran agamanya, sehingga sistem pendidikan islam tertinggal jauh di belakang non muslim (Barat). Karena itu modernisasi islam ini cenderung mengembangkan pesan Islam ke dalam konteks perubahan sosial dan perkembangan iptek serta melakukan liberalisasi penanganan yang adaptif terhadap kemajuan zaman, tanpa harus meninggalkan sikap kritis terhadap unsur negatif dari proses modernisasi.

Adapun model neo modernisme berusaha memahami ajaran-ajaran dan nilai mendasar terkandung dalam Al-Qur'an dan sunah dengan mempertimbangkan khazanah intelektual muslim klasik dan mencermati kesulitan dan kemudahan yang ditawarkan oleh dunia Iptek. Menurut Saiful Mujani, model ini mempunyai ketentuan- ketentuan tertentu.

Integrasi ilmu pengetahuan dalam era globalisasi, Al-Azhar cenderung sesuai dengan pola purifikasi, yaitu permasalahan yang ada dicarikan Al-Qur'an atau hadits yang relevan.

Model keterkaitan integrasi Imtaq dengan Iptek dalam masyarakat akademis dapat dilakukan antara lain dengan mengintegrasikan imtaq dalam proses pembelajaran dengan merencanakannya dan ditentukan bentuk integrasinya yaitu adanya keterkaitan Imtaq, Cara mengkaitkan dan Dituliskan ayat al-Qur'an atau hadits yang relevan dengan suatu kompetensi dasar.

Kerangka metodologis yang ditawarkan safi memadukan antara prisipprinsip analisis tekstual (kajian Al-Qur'an sebagai wahyu) dan prinsip-prinsip kajian historis (pengalaman empirik). Pada tahap awal metodologi terpadu bertolak dari kerangka kerja teoritis (Theoritical framework) yang pada dasarnya merupakan kumpulan ketentuan-ketentuan universal yang bersumber dari wahyu dan rekaman sejarah. Kerangka teoritis selanjutnya merupakan kumpulan ketentuan-ketentuan universal yang bersumber dari wahyu dan rekaman sejarah. Kerangka teoritis ini selanjutnya digunakan untuk menganalisis fenomena sosial melalui hipotesis tertentu yang dibuktikan lewat serangkaian pengamatan (observasi) .Dengan pendekatan terpadu , safi menjamin proses teorisasi dalam ilmu-ilmu sosial dalam berlangsung secara terbuka dan terus-menerus karena memungkinkan diperbaiki dan disempurnakan. Agaknya kerangka teoritik yang didasarkan dari wahyu dan rekaman sejarah tidak bersifat absolut dan sangat tergantung pada proses verifikasi, klarifikasi dan pengembangan yang konstan.

Sementara itu Fazlur Rahman agaknya tidak menganggap perlu adanya langkahlangkah itu. Menurutnya orang tidak dapat merancang satu metode tertentu untuk membimbing pemikiran manusia,sebab ia memiliki kerangka berfikirnya sendiri.13).

Dalam konteks ini, setidaknya ada tiga pendekatan alternatif yang bisa dilakukan oleh intektual muslim dalam mensikapi upaya rekonstruksi dan pendesaian sistem pendidikan, yaitu : Pertama, mengambil sistem pendidikan yang ditawarkan Barat an sich. Kedua, mengambil sistem pendidikan Islam lewat penggalian nilai-nilai atau sinyal-sinyal yang ada dalam al-Qur'an dan hadits an sich. Ketiga, melakukan asimilasi akomodatif antara sistem pendidikan yang ditawarkan Barat dengan nilai-nilai yang terdapat dalam ajaran Islam (al-Qur'an dan Hadits). Di sini dituntut sikap inklusifisme umat Islam dalam memandang ajaran Islam sebagai suatu yang fleksibel. Intelektual muslim dituntut untuk melakukan filterisasi nilai dari sitem pendidikan yang dikembangkan Barat dengan berbagai fenomena peradaban yang dihasilkan dengan ajaran yang terkandung dalam Al-qur'an dan Hadist, sebagai barometer dan sekaligus pewarna dari seluruh produk peradapan yang dihasilkan.

Sekolah merupakan suatu institusi sosial, yang wujud perkembangannya bergantung dengan institusi lain di masyarakat. Fungsi sekolah sebagai media pendidikan bagi generasi muda ditentukan

Tadarus Tarbawy. Vol. 2 No. 1 Jan-Jun 2020. ISSN. 2657-1285 e-ISSN. 2656-8756 
oleh beberapa faktor. Diantaranya, guruguru yang bukan hanya bisa mengajar mata pelajaran tertentu terutama mengembangkan nilai dan sikap yang diinginkan masingmasing murid. Dan ini tidak akan tercapai tanpa kurikulum sekolah yang rapi, termasuk daftar pelajaran, metode mengajar dengan berbagai model dan bahan-bahan pengajarannya, serta alat-alat penilaiannya.

Berkaitan dengan integrasi Ilmu pengetahuan, Al-Azhar memiliki dua sumber kurikulum yang dipergunakan dalam proses pembelajaran, yaitu (1) kurikulum Departemen Pendidikan Nasional (Depdiknas) untuk mata pelajaran umum, dan (2) Kurikulum Al-Azhar untuk mata pelajaran Pendidikan Agama. Kedua kurikulum tersebut dipersatukan, sehingga materi pelajaran umum disatukan secara langsung dengan nilai-nilai keimanan dan ketaqwaan. Di sekolah Islam Al-Azhar kurikulum tersebut diberi nama "Garis-Garis Besar Program Pengajaran (GBPP) Yang Dikaitkan Dengan Imtaq"

Berdasarkan hasil penelitian terdapat pendapat murid /siswa terhadap pelaksanaan terintegrasi, yaitu 1), Mayoritas siswa baik siswa SMP maupun siswa SMA, mendukung dan setuju terhadap pelaksanaan pembelajaran yang dilakukan secara terintegrasi, karena pembelajaran secara terintegrasi selain akan mempermudah siswa memahami pembelajaran yang diajarkan guru, juga dapat meningkatkan keimanan mereka. 2), Empat manfaat yang dirasakan siswa melalui pembelajaran yang dilakukan secara terintegrasi, yaitu (a) menjadi lebih hormat terhadap orang tua, (b) menjadi lebih bersyukur terhadap nikmat-nikmat yang diberikan Allah, (c) menjadi lebih pemaaf, dan (d) menjadi lebih optimis. 3).Siswa berpendapat guru, telah mulai melaksanakan pembelajaran terintegrasi, diindikasikan para guru mengkaitkan materi ajar yang disampaikan dengan nilai-nilai dan prilaku guru yang berhenti sejenak dalam menyampaikan materi pelajaran, ketika mendengar suara adzan. 4). Terdapat enam prilaku Islami, yang menurut siswa lebih banyak diperoleh di sekolah, dibandingkan keluarga, dan masyarakat. Prilaku-prilaku Islami tersebut secara hierarki adalah; ketertiban, mentaati peraturan yang ada, disiplin, memelihara sholat, toleransi dan menghargai perbedaan. 5). Guru yang paling besar mempengaruhi pembentukan prilaku Islami, secara hierarki adalah; guru agama. guru PKn, guru Ekonomi, guru Matematika, Kimia, Biologi, Fisika, Sejarah dan Geografi.

Adapun hasil analisis angket guru, Kepala Sekolah, wakil Kepala Sekolah, pengawas dan bidang, terhadap pembelajaran terintegrasi : 1).Belum semua guru mengetahui dan memahami tentang kurikulum terintegrasi. 2).Belum semua guru memiliki kompetensi yang sama dalam mengembangkan dan mengimplementasi kurikulum, khususnya kurikulum terintegrasi. 3).Variasi jawaban guru terhadap implementasi kurikulum terintegrasi selain menggambarkan adanya perbedaan persepsi juga karena tidak utuhnya informasi dan kurangnya sosialisasi. 4).Belum semua guru menjadikan kurikulum sebagai acuan, pedoman ataupun arahan, dalam merencanakan, mengelola, dan menilai pembelajaran. 5).Sebagian besar guru berpendapat evaluasi atau pemantauan (monitoring) secara kuantitatif agak sulit, belum berjalan baik. 6).Tiga cara yang dilakukan Kepala Sekolah, untuk mengetahui apakah guru memahami kurikulum terintegrasi, yaitu; (a) supervisi kelas, (b) melalui silabus, dan (c) saat PBM berlangsung. 7). Pengawasan yang dilakukan oleh pengawas terhadap PBM yang dilaksanakan guru belum maksimal, belum menyeluruh dan belum dilakukan untuk semua mata pelajaran. 8). Monitoring dan evaluasi yang dilakukan oleh pengawas terhadap implementasi kurikulum terintegrasi, adalah melalui dialog dengan guru untuk aplikasi di lapangan atau supervisi kelas, diskusi yang dilakukan dengan guru, melihat langsung pelaksanaan 
PBM, melaksanakan evaluasi langsung (secara lisan), memberikan catatan / rekomendasi yang diperlukan. 9). Peran Pengawas dalam implementasi kurikulum terintegrasi yakni melakukan supervisi kelas dan memberikan pembinaan tentang kurikulum terintegrasi. 10). Umumnya monitoring dan evaluasi yang dilakukan oleh Kepala Sekolah masih sebatas penguasaan kelas dan metode mengajar, belum menyentuh mengenai pelaksanaan kurikulum terintegrasi. 11). Menurut para guru kendala yang paling berat dalam melaksanakan kurikulum terintegrasi adalah kurangnya sumber acuan yang seragam dan kemudahan mendapatkan akses ke luar. Kesibukan masing-masing guru menyebabkan susahnya berkoordinasi dan berdiskusi dengan guru lain, untuk menindaklanjuti permasalahan yang ditemukan. Hal yang sama juga diakui oleh Kepala Sekolah, bahwa waktu di kelas sangat terbatas, serta kemampuan dan kesiapan guru yang belum homogen.

Dalam Islam menurut Azyumardi tidak dikenal pemisahan esensial antara "ilmu Agama" dengan "Ilmu Profan" Azyumardi mengatakan bahwa berbagai dan perspektif intelektual yang dikembangkan dalam Islam memang mempunyai hirarki. Tetapi hirarki ini pada akhirnya bermuara pada pengetahuan tentang "Yang Maha Tunggal". Subtansi dari segenap ilmu. Hal ini alasannya kenapa para ilmuan muslim berusaha untuk menginterasikan ilmu-ilmu yang dikembangkan peradaban-peradaban lain dalam skema hirarki ilmu pengetahuan menurut Islam.

Selanjutnya dengan menunjukan Nasr banyaknya ulama, filosof dan ilmuan muslim sejak dari al Kindi, al Farabi dan Ibu Sina sampai al-Ghazali, Nashiral-Din alThusi dan Mulla Sadra sangat peduli dengan klasifikasi ilmu-ilmu. Berbeda dengan dua klasifikasi yang dikemukakan di atas menurut Azyumardi, yakni ilmu-ilmu agama dan ilmu-ilmu umum, para pemikir ilmuan dan ilmuwan muslim di masa-masa awal membagi ilmu-ilmu pada intinya kepada dua bagian yang diibaratkan dengan dua sisi dari satu mata uang koin. Jadi esensinya tidak bisa dipisahkan. Yang pertama adalah alulum al-naqliyyah, yakni ilmu-ilmu yang disampaikan Tuhan melalui wahyu, tetapi melibatkan penggunaan akal. Yang kedua adalah al-ulum al-aqliyyah, yakni ilmu-ilmu intelek, yang diperoleh hampir sepenuhnya melalui penggunaan akal dan pengalaman empiris.

Menurut Azyumardi kedua bentuk ilmu ini secara bersama-sama di sebut alulum al-hushuli, yaitu ilmu-ilmu perolehan. Istilah terakhir ini digunakan untuk membedakan dengan "ilmu-ilmu" (ma'rifah) yang diperoleh melalui ilham (kasyf). Dan walaupun terdekat integralisme keilmuan seperti ini, setidaknya pada tingkat konseptual, tetapi pada tingkat lebih praktis, tak jarang terjadi disharmoni antara keduanya, atau lebih tegas antara wahyu dan akal, atau antara "Ilmu-ilmu agama" dengan sains. Untuk mengatasi disharmoni ini berbagai pemikir dan ilmuwan Muslim memunculkan klasifikasi ilmu-ilmu lengkap dengan hirarkinya. Selanjutnya dengan menunjuk pendapat Nasr, al Kindi adalah pemikir muslim pertama yang berusaha memecahkan persoalan ini dalam buku $F i$ Aqsam al-Ulum (jenis-jenis ilmu). Al Kindi disusul oleh al Farabi, yang memulai kitab Ihsha al-Ulum (buku urutan ilmu-ilmu) memainkan pengaruh lebih luas dalam hal ini. Namun pada mulanya kaum muslimin menerjemahkan karya-karya filsafat Yunani.14).

Tokoh-tokoh lain, seperti Ibnu Sina, al-Ghazali dan Ibnu Rusyd juga membuat klasifikasi ilmu-ilmu yang essensinya mengadopsi karangan Al Farabi dengan sedikitnya penyesuaian. Al Farabi membagi ilmu menjadi cabang besar, ilmu-ilmu bahasa, ilmu logika, ilmu-ilmu dasar (seperti Aritmatika, Geometri), ilmu-ilmu alam dan metafisika, dan ilmu-ilmu tentang masyarakat (seperti hukum dan theologi). 


\section{E. KESIMPULAN DAN SARAN}

Adapun hasil pembahasan tersebut kesimpulannya yaitu :

1. Perubahan pola pendidikan Islam dari masyarakat termarjinalkan ke masyarakat moderen dengan pola pendidikan yang diharapkan oleh umat, termasuk saat ini memasuki era zaman Millenial. .

2. Kebutuhan umat yang diinginkan pada masyarakat perkotaan yang sibuk dengan pekerjaan yaitu mengharapkan pola pendidikan berpengetahuan luas yang berlandaskan agama. Hal ini sesuai pola yang disampaikan oleh sekolah Al Azhar yaitu dengan mengintegrasikan Ilmu pengetahuan Umum dengan Ilmu Agama ( IPTEK dan IMTAQ ).

3. Sekolah Pendidikan Islam Al Azhar sebagai pelopor pendidikan Islam pada lingkungan elit perkotaan yang diikuti oleh lembaga pendidikan Islam lainnya sehingga merambah ke berbagai tempat termasuk di lingkungan perumahan-perumahan masyarakat ekonomi menengah atas.

Berdasarkan kajian tersebut penulis memberikan saran yaitu hendaknya kurikulum yang dikembangkan dengan memiliki keunggulan adanya integrasi ilmu pengetahuan dengan Imtaq maka lebih diinternalisasikan sehingga satu kesatuan yang tak terpisahkan ( Monotomi ).

\section{DAFTAR PUSTAKA}

1. Abdurrahman Mas'ud, Menggagas Format Pendidikan Non dikotomik, Yogyakarta,Gama Media, 2002,h. 44.

2. Husni Rahim, Horizon Baru Pengembangan Pendidikan Islam, Yogyakarta, UIN Press,2004,h. 51

3.Abu al-Hasan al-Nadwi, Pergulatan Iman dan Materialisme, Jakarta, Mizan, 1993.h.137.

4. Roger Geraudi, Janji-janji Islam,(terj),HM. Rasydi,Jakarta, Bulan Bintang,1983, Cet.I,h.56.
5 Mastuhu, The New Mind Set of National Education in The 2 st Centry, Yogyakarta, Safiria Indonesia Press, 2003,h. 158-160.

6.Willian C.Chittick,The Suf Path of Knowledge Hermeunetika Al-Qur'an Ibn Al-Arabi,cet.I, h. 37-38

7. Azyumardi Azra, Paradigma Baru Pendidikan Nasional: Rekonstruksi dan Demokratisasi, Jakarta, Penerbit Kompas,2001,h. 106.

8.Ikhrom, Dikhotomi Sistem Pendidikan Islam : Upaya menangkap sebabsebab dan Penyelesaiannya dalam buku Paradigma Pendidikan Islam (ed). Ismail SM,Yogyakarta, Pustaka Pelajar,2001,h. 87-89.

9. Munawir Sjadzali, Islam dan Tata Negara, Ajaran, Sejarah dan Pemikiran , Jakarta, UI Press, 1990,Cet.I, h. 1-2. Lihat pula A.Malik Fadjar, Reorientasi Pendidikan Islam Jakarta,Fajar Dunia, 1999,Cet.I, h. 27.

10.Husni Rahim, Horizon Baru Pengembangan Pendidikan Islam : Upaya merespon dinamika masyarakat global, Yogyakarta, UIN Press, 2004,h. 54.

11.Abuddin Nata dkk, Integrasi Ilmu Agama dan Ilmu Umum, Jakarta, UIN Jakarta Press, 2003, h. 173.

12.Louay Safi, Ancangan Metodologi Alternatif, Yogyakarta, PT. Tiara Wacana Yogya, 2001h. 7.

13. Husni Rahim, UIN dan Tantangan meretas Dikotomi Keilmuwan, Malang, UIN Press, 2004, Cet. I, h.55. 14.Baca Azyumardi dalam pengantar Pendidikan Islam Tradisi dan Modernisasi dan kemudian bandingan dengan pendapat Saleh Iskandar Poeradisastra, Sumbangan Islam kepada Ilmu dan Peradapan Modren, P3M, 2006, Cet III, h.62-68 